\title{
THE TAXATION OF FOREIGN INVESTMENT INCOME IN CANADA, THE UNITED STATES AND MEXICO*
}

\author{
Glenn P. Jenkins, † Devendranauth Misir** \\ and GRAHAM GLENDAY††
}

The taxation of income flows derived from foreign investment crossing national boundaries has undergone many significant changes during the 1970 s. Both host ${ }^{1}$ and home ${ }^{2}$ countries have adopted tax policies which have affected the flows of international income. Many of these policies were introduced with an intention of achieving a greater degree of international efficiency and equity in the taxation systems, and at the same time of permitting more efficient corporate tax planning. Revenue considerations undoubtedly played an important role as well.

Canada, the United States and Mexico are all committed to the basic policy that international business income should not be subject to double taxation, and the policy instrument adopted to achieve this objective is their respective foreign tax credit provisions in their taxing statutes. In the case of the United States and Canada, this is further enhanced by the United States-Canada Tax Treaty. ${ }^{3}$ Mexico has not signed any tax treaty for the avoidance of double taxation.

This article provides an overview of the taxation of foreign source income in Canada, the United States and Mexico and provides some empirical estimates as an example of the relative impact of a series of changes in Canadian taxation of foreign source income on (a) the change in the Canadian tax revenues and (b) the change in the incentive for U.S. residents to invest in Canada.

Since U.S. residents are the largest owners of foreign investments, American

Copyright (C) 1981 by Law and Contemporary Problems

*The authors wish to thank both Robert Conrad and Antal Deutsch for their many helpful comments and suggestions. This paper draws heavily on the research one of the authors has undertaken with Antal Deutsch. All errors and omissions that remain are the responsibility of the authors.

fInstitute Fellow Harvard Institute for International Development.

** Research Associate, Osgoode Hall Law School, York University.

†tLecturer in Economics, York University.

1. The host country of the investment is the jurisdiction in which the income is earned. The exact tax treatment of business income would depend on whether the firm is a branch plant or a foreign affiliate, but the host country usually taxes business income earned by foreign owned capital as if it were earned by a locally owned corporation, regardless of its ultimate destination.

2. The home country of the investment is the jurisdiction of which the investor is a citizen or a tax resident, or deemed to be a tax resident. In the case of a corporation, the home country is usually its place of incorporation.

3. March 4, 1942, 56 Stat. 1399, T.S. No. 983. A new and more comprehensive United States-Canada Tax Treaty has been signed but early ratification seems unlikely because of the current U.S. concerns about the border broadcasting disputes and certain provisions of the National Energy Program which are seriously affecting U.S. investment in Canadian oil and gas industry. 
tax policy has dominated the issues in this field of taxation. At the same time the host countries have become more aware that one of the greatest benefits they receive from the presence of foreign investment is the tax revenue they are able to collect from the income generated by these investments. This issue has tended to dominate the discussion with foreign investors in those countries where such investment has been related to the extraction of natural resources. The exception to this general observation has been Canada, where throughout the past decade the discussion of foreign investment has been concentrated on the real and imaginary (and usually unquantified) benefits and costs of technological transfers, technical and economic domination, regional job creation, and the promotion of manufacturing.

Accompanying the rise in the taxation of income from foreign-owned investment by host countries (exemplified in the extreme by the OPEC countries) has been the significant attention focused on the foreign tax credit provisions of the U.S. corporate income tax system.

\section{I}

Tax Treatment of Foreign Source Income in Canada, the United States and Mexico

\section{A. Some Common Characteristics}

Canada, the United States and Mexico tax their residents and citizens on their worldwide income, and provide limited foreign tax credit for taxes paid to host countries. In all three countries, the foreign tax credit available under the tax laws is basically the lesser of the foreign income tax paid on the foreign source income or the domestic tax on such foreign source income. The general administrative approach of the Revenue Departments seems to be one of restricting the availability of the foreign tax credit by requiring a "reasonable" apportionment of several domestic expenses and deductions to reduce foreign source income even where there are no specific provisions in the tax laws for allocating such expenses and deductions. This approach to tax administration would most likely lead to an increase in the overall taxation of foreign source income and a reduction in double taxation relief. ${ }^{4}$ Changes in January 1977 of section 861 of the Internal Revenue Code of the United States and the regulations thereunder seem to reflect this restrictive attitude of the U.S. Treasury Department.

The basic principles underlying the taxation of foreign source income and the allowance of a foreign tax credit includes the need for tax neutrality between domestic and foreign investors, the recognition of the primary right of the source country to tax income earned there, and the desire to develop an international equity approach to taxation.

4. Where this apportionment of domestic expenses against foreign income is in excess of actual domestic expenses incurred to earn foreign income, and where the foreign tax rate exceeds the domestic, then the total world-wide taxes of the firm and the domestic taxes payable are increased by the excess expenses multiplied by the domestic tax rate. 


\section{B. Canada}

Under section 126 of the Income Tax Act, a Canadian resident taxpayer is entitled to a foreign tax credit against the Canadian tax that would otherwise be payable on foreign source income. There are three important features of the foreign tax credit provisions which should be noted in this overview. ${ }^{5}$ First, the credit is computed on a per country basis rather than on a global basis as is done in the United States. ${ }^{6}$ Since Canada treats each country as a separate unit, it thereby limits the credit to the amount of Canadian tax on the foreign source income from each country. Second, a distinction is made between business income $\operatorname{tax}^{7}$ and nonbusiness income $\operatorname{tax}^{8}$ and thus separate calculations are made for foreign taxes on the business income and the nonbusiness income arising from each country. The distinction is an integral aspect of the credit system, because the choice of the applicable scheme for calculations is contingent on whether a particular income tax is characterized as a business or nonbusiness income tax. For example, a foreign tax credit is available only on an annual basis with no carryforward or carrybackward in the case of nonbusiness income tax, whereas in the case of credit for business income tax, a five-year carryforward is permitted. ${ }^{9}$ Third, there is a proportionate limitation where the maximum credit granted for foreign taxes paid is the full domestic tax otherwise payable on the foreign source income. ${ }^{10}$ The operation of this limitation means that the minimum rate of tax paid on the foreign source income is the Canadian rate. If the foreign tax rate is less than that of Canada, then Canada imposes a tax at the rate equal to the excess of the Canadian rate over the foreign rate. If the foreign rate is equal to or in exess of the Canadian rate then no Canadian tax is paid on the foreign source income. Again, in applying this limitation, separate calculation are made on a per country basis, as well as with respect to business income and nonbusiness income taxes.

Ultimately, the fragmented method of calculating foreign tax credits may lead to substantial uncertainty and confusion in the application of foreign tax credit provisions. Given that multinational enterprises carry on business in several countries, it becomes necessary to determine the amount of foreign source income of Canadian resident taxpayers from the respective host countries. The Income Tax

5. See Interpretation Bulletin IT1270, Foreign Tax Credit and Deductions, Department of National Revenue, Taxation, Nov. 17, 1975.

6. Income Tax Act $\S 126(1)$, (2), c. 63 Can. Stat. 1131 (1971) [hereinafter cited as Income Tax Act].

7. Subsection 126(7)(a) defines "business-income tax" as any income or profits taxes paid by the taxpayer to a foreign country or any state, province or other political subdivision of that country that may reasonably be regarded as tax which was paid on the income from any business carried on by the taxpayer in the foreign country.

8. Subsection 126(7)(c) defines "non-business-income tax" as any other income or profits taxes paid by the taxpayer to a foreign country, or any state, province or other political subdivision of that country which was not included in the computation of the taxpayer's "business-income tax". However, by virtue of subsection 20(11), this does not include any foreign taxes in excess of 15 percent paid on property income earned by the individual taxpayer. In addition, the definition does not include foreign taxes on property income or capital gains which the taxpayer chooses under subsection 20(12) to take as deduction in computing his income.

9. Subsection 126(7)(b) provides a method for the calculation of "foreign-tax carryover" which in effect allows business income tax paid in a particular year which is in excess of the amount creditable for that year to be carried forward for a period of five years.

10. Income Tax Act $\S 126(1)$, (2). 
Act does not provide any method for determining the territorial sources of income, but the Act requires the allocation of expenses to various territorial sources of income. Subsection 4(1) requires that in the computation of the taxpayer's income only deductions that may be "reasonably" regarded as wholly applicable to that part of the business carried on in a particular place should be allocated to such income. Apparently, before a Canadian resident taxpayer can allocate business expenses, he must establish the territorial sources of income. This allocation of expenses and other deductions among the various territorial sources in which the Canadian multinational enterprise does business, in order to benefit from the foreign tax credit provisions, may lead to substantial doubts in application of those provisions. One area where this allocation problem would create difficulties, for example, is transfer pricing.

\section{United States}

Although the United States asserts its taxing jurisdiction over the foreign source income of its citizens and residents, sections 901 and 903 of the Internal Revenue Code grant a foreign tax credit for income taxes or taxes paid in lieu of income taxes on the foreign source income of other countries. ${ }^{11}$ The U.S. foreign tax credit is computed on a global basis, and thus all income from foreign sources is totalled and a single foreign income tax credit is calculated.

In general, the U.S. citizen or resident is taxed, nominally, at the higher of the rates charged by the host country or the United States on his foreign source income. This is accomplished by subjecting patriated foreign earned income to regular U.S. tax rates, but allowing credits toward U.S. tax liabilities for income taxes incurred abroad, limited to the amount of U.S. taxes due on the foreign source income. ${ }^{12}$ For countries where local income taxes are higher than those charged in the United States, the taxpayer is left with a surplus of tax credits over and above what can be used to offset U.S. rates on the foreign income. Where the local rates are lower than U.S. rates, there will not be enough tax credits generated to offset the entire U.S. tax liability. The latter situation is referred to as a deficit of foreign tax credits. Under the rules of the U.S. foreign tax credit system, the U.S. taxpayer may pool the tax credit surpluses earned in one country with the deficits originating in another country. ${ }^{13}$ The consequence is to allow U. S. taxpayers to arrange their affairs so that their foreign source income is taxed at an effective rate

11. Internal Revenue Code sections 882 and 871 (b) impose a tax on foreign source income of foreign corporations and nonresident aliens, respectively, that is "effectively connected" with a business in the United States. However, section 906 of the Internal Revenue Code provides a limited form of foreign tax credit for some foreign income taxes paid with respect to this income. Under paragraph 901(b), foreigners are entitled to the foreign tax credit but the section 906 credit is granted only for taxes that qualify under sections 901 and 903 and which, in addition are paid or accrued during the taxable year with respect to income effectively connected with the conduct of business in the United States. Thus, in addition to the special rules in section 906 , the basic rules used in the ordinary foreign tax credit are applicable. In contrast, the foreign source income of a nonresident is not subject to Canadian tax of any kind

12. See I.R.C. $\$ \$ 901-904$ and regulations thereunder. The most thorough, though now somewhat dated, reference work on this subject, is OWENS, THE FOREIGN TAX CREDIT (1961). A more recent work on this subject by the same author is INTER NATIONAL ASPECTS OF U.S. INCOME TAXATION: CASES AND MATERIALS (1980), published in three volumes by Harvard Law School.

13. Some exceptions to this rule apply to the tax credits created from taxes paid on the production of 
approximating their marginal rate on U.S. source income. This is possible because the U.S. foreign tax credits are computed on a global basis, and thus there is only the overall global limitation on available foreign tax credits.

The overali foreign tax credit limitation may provide an incentive for U.S. investors, with foreign source profits that are taxed relatively highly, to take steps to assure that all foreign taxes are creditable. For example, they may choose to reorganize or increase their foreign investments in less heavily taxed jurisdictions, or to engage in business activities which may increase their foreign source income in order to lower the overall effective foreign tax rate. ${ }^{14}$

It should be noted that a U.S. corporate shareholder, owning at least 10 percent of the voting power of a foreign corporation which has paid a dividend out of accumulated profits, is permitted under section 902 of the Internal Revenue Code to credit a proportionate amount of the foreign income taxes paid by the foreign corporation on its earnings. ${ }^{15}$ This credit is usually referred to as the "deemed paid" or indirect foreign tax credit.

In general the U.S. taxpayer has the option of treating all direct foreign taxes paid as a deductible expense (under section 164 of the Internal Revenue Code) rather than claiming a foreign tax credit. However, the credit is usually regarded as being more advantageous to a taxpayer than a deduction, except perhaps where the taxpayer suffers an overall loss. ${ }^{16}$

Another important difference between the U.S. and Canadian foreign tax credit provisions is that the U.S. tax code provides general rules in section 861 for determining territorial sources of income for the calculation of the foreign tax credit. In addition, the regulations under section 861 provide several methods of allocating expenses between U.S. and foreign source income.

One objective of international corporate planning is to minimize global tax obligations by not accumulating excess, and potentially unusable, tax credits. Some of the elements that enter into tax planning are: (i) the shifting of earnings to low-tax countries so as to create tax credit deficits; (ii) the rechanneling of accounting profits into management fees or into interest payments on intercorporate debt; ${ }^{17}$ and (iii) the deferral of both the subsidiary earnings patriation and the accompanying U.S. tax liability.

The possibility of deferring the reporting of subsidiary income as U.S. taxable

petroleum outside the United States. See BURKE \& BOWHAY, InCOME TAXATION OF Natural RESOURCES 2913 (1979).

14. See Hammer \& Chan, The U.S. Foreign Tax Credil-New Implications for Canada, 26 CAN. TAx J. 438 (1978).

15. In the United States, domestic corporations must include in their taxable income all dividends received from foreign subsidiaries and affiliates. Such dividends are not included in taxable income of Canadian resident corporations if paid out of active business income of foreign affiliates earned in any country listed in subsection 5907(11) of the Income Tax Regulations.

16. Hammer \& Chan, supra note 14 , at 434 .

17. These payments are usually taxed at rates different from those levied on dividends. In the case of Canada, bona fide management charges or payments of interest between private parties are subject only to the 15 percent withholding tax (reduced by treaty from the 25 percent rate dictated in Income Tax Act section $212(1)$ ), but not to the regular tax on corporate profits. Where a U.S. corporation borrows at home and uses the proceeds to lend to its foreign subsidiary, the borrowing costs may be deducted against U.S. source income. The interest payments of the foreign subsidiary reduce its taxable profits. 
income until dividends are actually paid creates a situation in which if the host country's taxes are lower than those of the United States, the multinational corporation may gain from reinvestment of earnings in the subsidiary and postponement of the U.S. tax liability. In such a case some incentive for expansion is lost when the host country increases its tax rates even though they remain below the rate of the U.S. corporate income tax. ${ }^{18}$ The governments of countries which act as hosts to the U.S. source investment have objectives of their own to pursue. Two of the most important are the encouragement of economic activity in the sector where the U.S. investment is located, and the collection of revenue from it. If deferral of the taxation of subsidiary profits were not allowed by the U.S. Treasury, and if the U.S. investor did not have surplus tax credits elsewhere, no trade-off would exist between these two policy objectives until the host country's effective tax rate on the income from foreign investment reached that of the United States. The incentive given to the tax planners for U.S. investors can only be changed if the rate of host country taxation exceeds that of the United States.

If a multinational corporation is operating in several countries and has accumulated an overall excess of foreign tax credits, an increase in the income tax rates of any one of the host countries, even if its initial rate is below that of the United States, will result in a decrease in the incentive to invest in that country. The increase in the host country's tax rate will increase the multinational corporation's stock of foreign tax credits to be carried forward for future use. The present value of these excess tax credits to the multinational corporation, however, will always be less than their current nominal value.

In the 1970s the increased host country taxes on the activities of the U.S.owned oil companies resulted in a significant build up of excess tax credits by these firms. This prompted many of these firms to diversify into other activities in countries where taxes on income were below the U.S. rates. The U.S. government's reaction to this prospect has been both to restrict the activities to which the excess foreign tax credits generated by the petroleum industry can be applied and to become more strict in determining which payments are allowed as foreign tax credits. ${ }^{19}$

The ultimate impact of any change in Canadian, Mexican or other foreign country's taxation on the incentive for U.S. residents to invest in the foreign country depends critically on whether or not the tax generates U.S. foreign tax credits. It is important, therefore, to review some of the recent rulings by the Internal Revenue Service defining what precisely is foreign tax. ${ }^{20}$ Prior to 1976 , the generally accepted definition of what constituted a creditable tax in the United States

18. If deferred taxes are reinvested in the host country, there will normally be no present value cost to the United States from deferred tax payments. Deferral aids the U.S. parent because it allows added flexibility to patriate dividends so as to utilize more effectively its foreign tax credits.

19. The result is a set of regulations described in the U.S. Department of Treasury, News Release, Nov. 12, 1980.

20. This review draws heavily on discussions one of the authors has had with Robert Conrad, and his excellent review of recent changes in the U.S. treatment of foreign taxes found in Chapter V of Tax Incentives for Foreign Investment in Non-Fuel Mineral Industries, Final Report Contract No. OA 79-4, The Office of International Tax Affairs, Office of Tax Analysis, U.S. Department of Treasury, December 1980. 
was a foreign tax that was similar in both "structure and intent" to the U.S. tax."1 If a foreign tax was not creditable because it was not an income tax levied on either a U.S. branch or subsidiary, ${ }^{22}$ it might nevertheless be declared creditable under the "in lieu of" provision. ${ }^{23}$ The regulations under this provision set forth three requirements, other than an income tax, for a payment to a foreign government to qualify as a creditable tax. ${ }^{24}$ First, the country must have in force a general income tax law. Second, the taxpayer claiming the credit must be subject to the other tax. Third, the general income tax must not be imposed on the taxpayer.

In spite of the above provisions, there has always been some ambiguity in the definition of creditable tax. This ambiguity has caused the greatest difficulty in the cases of petroleum, mineral and other natural resource operations. In these activities the mineral rights in most countries are held by the state, and as a result, operating firms are often required to pay both income taxes and royalties (or other production tax) to the host country. Because both tax payments are made to the host government, it may be not clear from the structure of the tax system which tax or part of a tax is a tax on "income" and which is a factor payment. If the royalty is made as a payment to the owner for the extracted mineral resource, then to declare it a creditable tax would be to allow a tax credit for wages paid to workers in the foreign country. This ambiguity has been the subject of numerous rulings and court cases.

The Internal Revenue Service issued three rulings in January 1978 which have forced a review of the determinants of a creditable tax. Briefly, Revenue Ruling $78-61^{25}$ stated that the Province of Ontario Mining Tax was not a creditable tax because expenses such as interest deductions, royalty payments to the landowner, and exploration expenses were not allowed as deductions in computing the base. In addition, the Internal Revenue Service stated three requirements for use in determining whether or not a foreign payment was a creditable tax. ${ }^{26}$ First, the base of the foreign tax must be "realized in the United States' sense." Second, the tax should be so structured as to tax only the "net" gain after its realization. Finally, a foreign tax must be imposed on the receipt of income "rather than on transactions such as sales or the exercise of a privilege or a franchise" (i.e., a mineral royalty).

The three principles stated in Revenue Ruling 78-61 were expanded in Revenue Rulings 78-62 27 and 78-63.28. The first ruling declared a French domicile tax to be noncreditable because it was based on "estimated" income. The latter ruling

21. For the history of this debate, see the two works by Owens, supra note 12.

22. This is covered in sections 901 and 902 of the Internal Revenue Code. Section 901 states that a U.S. citizen or domestic corportion is allowed a credit for: "the amount of any income, war profits, and excess profits taxes paid or accrued during the taxable year to any foreign country or to any possession of the United States," subject to limitations of section 904. The definition of creditable taxes in section 902 is the same as that found in sections 901 and 903 .

23. Section 903 states that: "the term 'income, war profits, and excess profits taxes' shall include a tax paid in lieu of a tax on income, war profits, or excess profits otherwise generally imposed by any foreign country or by any possession of the United States".

24. Treas. Reg. $\$ 1.903-1$.

25. 1978-1 C.B. 221.

26. Id. at $223-24$.

27. 1978-1 C.B. 226.

28. 1978-1 C.B. 228. 
changed the Internal Revenue Service's previously held positions regarding Libyan and Saudi Arabian petroleum taxes. ${ }^{29}$ The Internal Revenue Service stated in this ruling that a tax base determined through the use of "posted prices" was "artifical or fictitious" and therefore the tax imposed was noncreditable.

These three rulings elicited expressions of concern by several parties that the Internal Revenue Service was, in fact, legislating new law. ${ }^{30}$ The Internal Revenue Service stated that it would study the entire area and issue new regulations which would clarify its position. Because of the importance of these rulings for foreign investment income, the Internal Revenue Service issued "guidelines" for creditability in July 1978. ${ }^{31}$ The guidelines state that if a foreign government owns the mineral rights, a tax will be creditable if the host government requires another "payment of an appropriate royalty" and all of the following conditions are satisfied:

(1). The amount of income tax is calculated separately and independently of the amount of the royalty and of any other tax or charge imposed by the foreign government.

(2). Under the foreign law and in its actual administration the income tax is imposed on the receipt of income by the taxpayer and such income is determined on the basis of arm's length amounts. Further, these receipts are actually realized in a manner consistent with U.S. income taxation principles.

(3). The taxpayer's income tax liability cannot be discharged from property owned by the foreign government.

(4). The foreign income tax liability, if any, is computed on the basis of the taxpayer's entire extractive operations within the foreign country.

(5). While the foreign tax base need not be identical or nearly identical with the U.S. tax base, the taxpayer, in computing the income subject to the foreign income tax, is allowed to deduct without limitation significant expenses paid or incurred. Reasonable limitations on the recovery of capital expenditures are acceptable. ${ }^{32}$

After further comment and study, temporary regulations were issued on November 12, 1980.33 These new regulations maintain the spirit and intent of the 1978 rulings and contain several examples relating to specific technical issues. The new regulations state that a foreign charge is a creditable tax under the provisions of section 901 "if and only if:" (1) "the charge is not compensation for a specific economic benefit," (2) "the charge is based on realized net income," and (3) "the charge follows reasonable rules regarding source of income, residence or other bases for taxing jurisdiction." The regulations also state that the basis for comparision in the determination of creditability is the U.S. tax system. The regulations for section 903's "in lieu of" provision are also expanded to include a more stringent "substitution" requirement as well as an additional "comparability" requirement. The comparability requirement seeks to ensure that the liability for the substitute tax will not be "significantly greater than" the general income tax.

In summary, the Internal Revenue has developed more stringent requirements

29. See Rev. Rul. 55-296, 1955-1 C.B. 386; Rev. Rul. 68-552, 1968-2 C.B. 306.

30. See, e.g., Foreign Tax Credit Subcommittee, Committee on Foreign Activities of U.S. Taxpayers, Section of Taxation, A.B.A., The Credilability of Foreign Income Taxes: A Critical Analysis of Revenue Rulings $78-$ 61, 78-62 and 78-63, 32 TAX LAWYER 33 (1978).

31. Internal Revenue Service, Department of Treasury, News Release, I.R. No. 1638, July $16,1978$.

32. Id.

33. Temp. Treas. Reg. $\$ \S 4.901-2$ and 4.903-1, T.D. 7739, 1981-1 I.R.B. 15. The regulations also require that the charge cannot be related to the availability of a foreign tax credit (i.e. "sop up" taxes). 
for creditability of a foreign tax. This new emphasis could have a substantial effect on the behavior of U.S. investors abroad unless host governments can change their tax laws to conform with the new guidelines. Since all "non-creditable" foreign charges are deductible in computing U.S. taxes, a loss of credits could mean a reduction of up to approximately one-half the value of this charge for U.S. tax purposes. This fact could increase the total tax bill of U.S. foreign operations and may change the relative incentives for foreign versus domestic investment. In addition, this trend toward increased U.S. taxation of foreign investment income is strengthened by the requirement that certain domestic expenses be deducted from foreign investment income. ${ }^{34}$

\section{Mexico}

Mexico taxes its residents and citizens on their worldwide income but does provide limited relief from double taxation through the foreign tax credit provisions of its taxing statutes. Unlike Canada and the United States, Mexico has signed no tax treaties with any country for the avoidance of double taxation. Article 3 of the Income Tax Act provides for the foreign tax credit with respect to income taxes paid on the foreign source income to the host country. The credit is limited to the lower of the foreign income tax paid or the Mexican income tax payable on the foreign source income. The Act does not provide for the allocation of domestic expenses to the foreign source income but the tax administrative authority (Treasury Department) does require an apportionment of domestic expenses that are related to such foreign source income to reduce the foreign source income, and thus restricts the availability of the foreign tax credit. ${ }^{35}$

Overall, it would appear that Mexico does not provide the same amount of relief from double taxation as do the United States and Canada. Mexico has no tax treaty with any country, and in addition, the foreign tax credit provision does not allow for carryforward or carrybackward of any excess of foreign tax credit. The Mexican system is also governed by both the "overall" and the "country-bycountry" limitations.

The Organization of Economic Cooperation and Development Draft Model Treaty has been adopted by most countries as the basis for international tax treaties, and is no doubt a major reason why Mexico has not entered into any such treaties. The OECD Model Treaty has been criticized by several developing countries as having a bias toward the developed countries and as having the practical effect of shifting a large proportion of income tax revenues, to which the developing countries seem to have a legitimate and equitable claim, from their treasuries to those of the developed countries. ${ }^{36}$ Because of this, it would appear that Mexico is not inclined to enter into tax treaties with other countries unless the League of Nations Mexican Model Treaty of 1943 is used as the basis for the treaty. The

34. Hammer \& Chan, supra note 14, at 443. See also the discussion in Section IA above.

35. Price Waterhouse, Doing Business in Mexico (1979).

36. See World Association of Lawyers, Committee on Taxation, The Emerging International Tax Code, 10 Tax Management INT'L J. 39(1977); Irish, International Double Taxation Agreements and Income Taxation at Source, 23 INT'L \& COMP. L. Q. 292 (1974). 
Mexican Model Treaty was drafted with a bias for taxing income at source rather than residence and would thus provide a model for tax treaties that would go far in removing the adverse effects suffered by several developing countries.

It is clear, however, that a U.S.-style system of foreign tax credits effectively results in taxation of income at source rather than residence with the proviso that if the home country has a higher tax rate than the host country, then the home country collects the excess tax revenues. Firms located in high-tax home countries are then indifferent, from a taxation perspective, between investing in the home or a low-tax host country. Alternatively, if income from operations in a host country is taxed only at the low tax rate of that country, then the firm will have an incentive to increase its investments there, and hence, increase the tax revenues of the host country.

\section{Canadian Tax Policy Ghanges: Effects on Tax Revenue and U.S. InVESTMENT INCENTIVES IN CANADA}

To illustrate the magnitude of the effects of changes in income tax policy on the tax revenues of host and home countries as well as the incentives to undertake foreign investments, some examples are drawn from U.S. investments in Canada. ${ }^{37}$ Estimates in U.S. dollars of the change in Canadian tax revenues, the change in U.S. tax revenues, and the change in total net taxes paid by foreign investors are given for the following three policy alterations based on data for 1972 and 1974:38

A. An increase in the Canadian withholding tax rate on dividends and branch profits from 15 to 25 percent;

B. A decrease in the Canadian withholding tax rates on dividends and branch profits from 15 to 10 percent;

C. A reverse of the 46 to 40 percent reduction in the nominal Canadian tax rate on corporate income from manufacturing.

A. Increase in the Withholding Tax Rate on Dividends and Branch Profits from 15 to 25 Percent

Under the provisions of the Canada-United States Tax Treaty ${ }^{39}$ in effect at the time of writing (the 1942 Treaty, as modified in 1950, 1956 and 1966), Canada has been withholding 15 percent of subsidiary dividends and branch profits paid by Canadian operations to their U.S. parents. Canadian legislation stipulates a general withholding rate of 25 percent that is reduced by treaty between Canada and the United States. ${ }^{40}$ If the general rate were to be applied to the Canadian source

37. The aggregate of U.S. interest, branch profits and dividends patriated from Canada in 1974, the last year for which information broken down by industry was available, was $\$ 1,180$ million. By 1978 this had grown to a total of $\$ 1,554$ million. See U.S. Department of Commerce, Survey OF CurRent Business-CU.S. InTERnATIONAL InVESTMENT POSITION 1978 (1979).

38. The estimates presented here are taken from Deutsch \& Jenkins, Tax Incentives, Revenue Transfers and the Taxation of Income from Foreign Investment, in TAX POLICY OPTIONS IN THE 1980s (J. Whalley \& W. Thirsk eds. 1981). Reference should be made to this paper for data sources and methodology.

39. See note 3 supra.

40. "Generally, under bilateral tax agreements, the rate of withholding tax is 15 percent, although a 
dividends and branch profit income of U.S.-based corporations, the government of Canada would, at least in the short run, collect more revenues. The task here is to estimate how much of these revenues would come from a decrease (through new tax credits) in U.S. taxes paid, given that the remaining sums would come out of the coffers of the tax paying corporations.

These amounts are estimated in Summary Table I for each of 1972 and 1974 in two ways. The first, which uses potential tax credits for each industrial sector, provides an estimate of the maximum amount of foreign tax credits each industry could claim based on its creditable income tax payments made outside the United States in that year plus any carryforward of excess tax credits from the previous years. ${ }^{41}$

The second measure of the incentive and tax transfer effects of an increase in the Canadian withholding tax is based on the actual tax credits claimed on returns filed. If an industry utilizes fewer tax credits than it has U.S. tax liabilities on its foreign earned income, then the sector is classified as having a deficit of tax credits, even if after aggregating all the companies in a sector it appears that there are sufficient foreign tax credits to cover the deficit.

The results presented in Summary Table I indicate that increasing the Canadian withholding tax to 25 percent would have led to no more than seven of twenty-six industries experiencing an increase in overall tax liabilities in 1972, while only three of twenty-one industries would have had their taxes increased in 1974. Canadian tax revenues would have increased by approximately $\$ 180$ million in 1972 and $\$ 193$ million in 1974 . The bulk (66 to 100 percent) of these funds in each year, $\$ 119$ million to $\$ 180$ million in 1972 , and $\$ 154$ million to $\$ 157$ million in 1974, effectively would have been paid by the United States through higher foreign tax credits being used to offset U.S. tax liabilities. Of the remainder, a large proportion of the burden in 1972 remained with "Motor Vehicles and Equipment" (\$17 million) and in 1974 with "Petroleum Refining" (\$28 million), "All Other Mining" (\$44 to 6 million) and "Wholesale Trade" ( $\$ 4$ million). In each of the above cases, the lowest estimate of the tax transfer from the U.S. Treasury corresponds to the case where it is assumed that all the foreign tax credits can potentially be used to decrease the U.S. tax liability on foreign source income in the industry.

statutory rate of 25 percent is provided for in the Act." Canadian Master Tax Guide 1981 (CCH Canadian Ltd.) If 13,060 .

41. Because of the nature of the data base, this estimate of maximum foreign tax credits implies the assumption that the excess tax credits of one firm within an industry could be used to offset the deficits of another. This practice is in fact not allowed; thus this procedure underestimates the negative incentive effect of an increase in Canadian tax rates on U.S. companies operating in Canada if the companies already have a surplus of tax credits. On the other hand, it will underestimate the tax transfer effect (from the Canadian to the U.S. Treasury) and hence overestimate the incentive effect for these companies that have a deficit of tax credits, when Canada raises its withholding or other income taxes. The results indicate that U.S. companies operating in Canada tend to have a deficit of tax credits with fewer foreign tax credits being used and more U.S. taxes being paid than would be predicted by the industry aggregates. Thus it appears that the industry averages understate the degree to which individual U.S. companies operating in Canada have a deficit of foreign tax credits. See Deutsch \& Jenkins, supra note 35, app. 


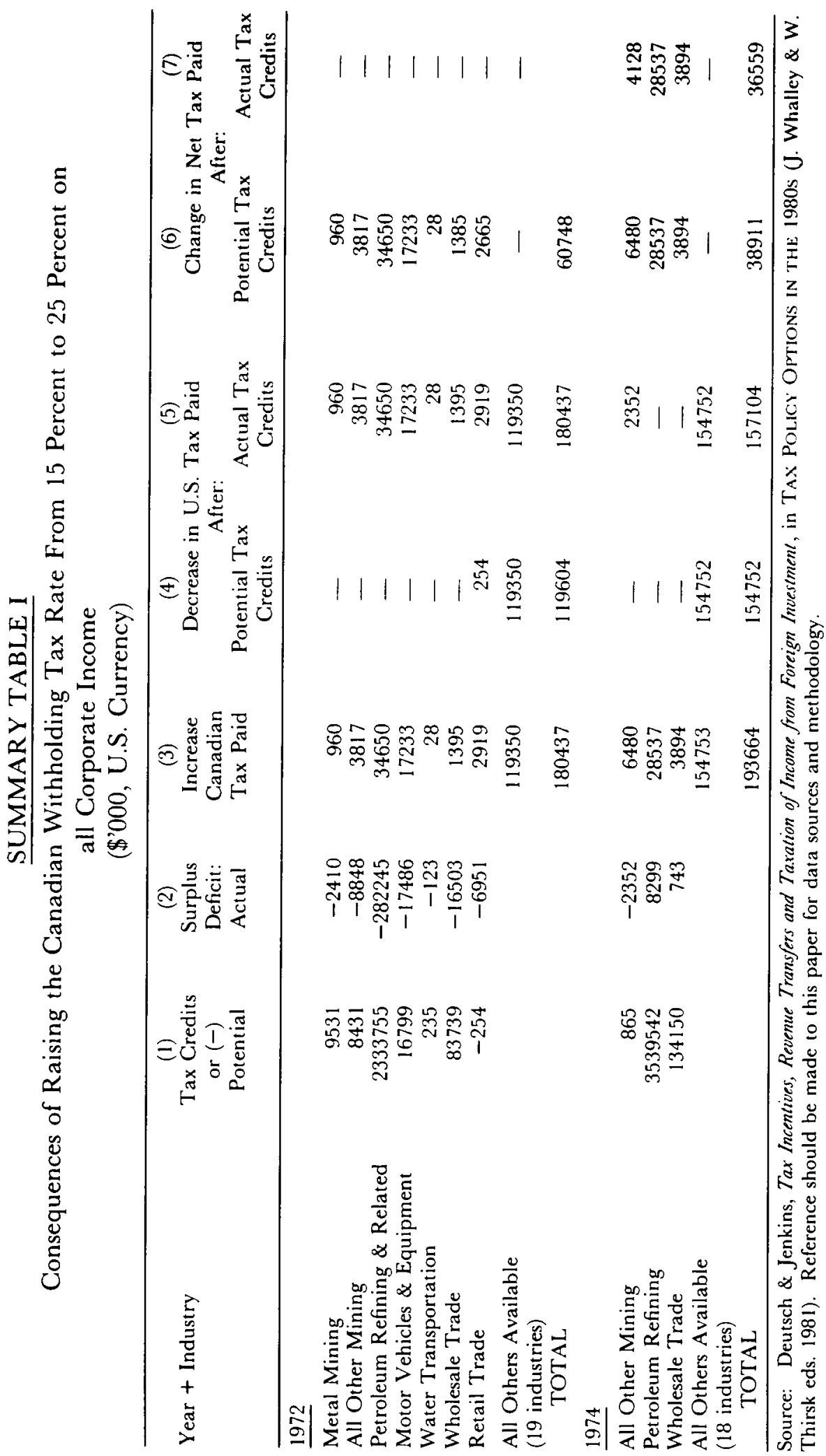




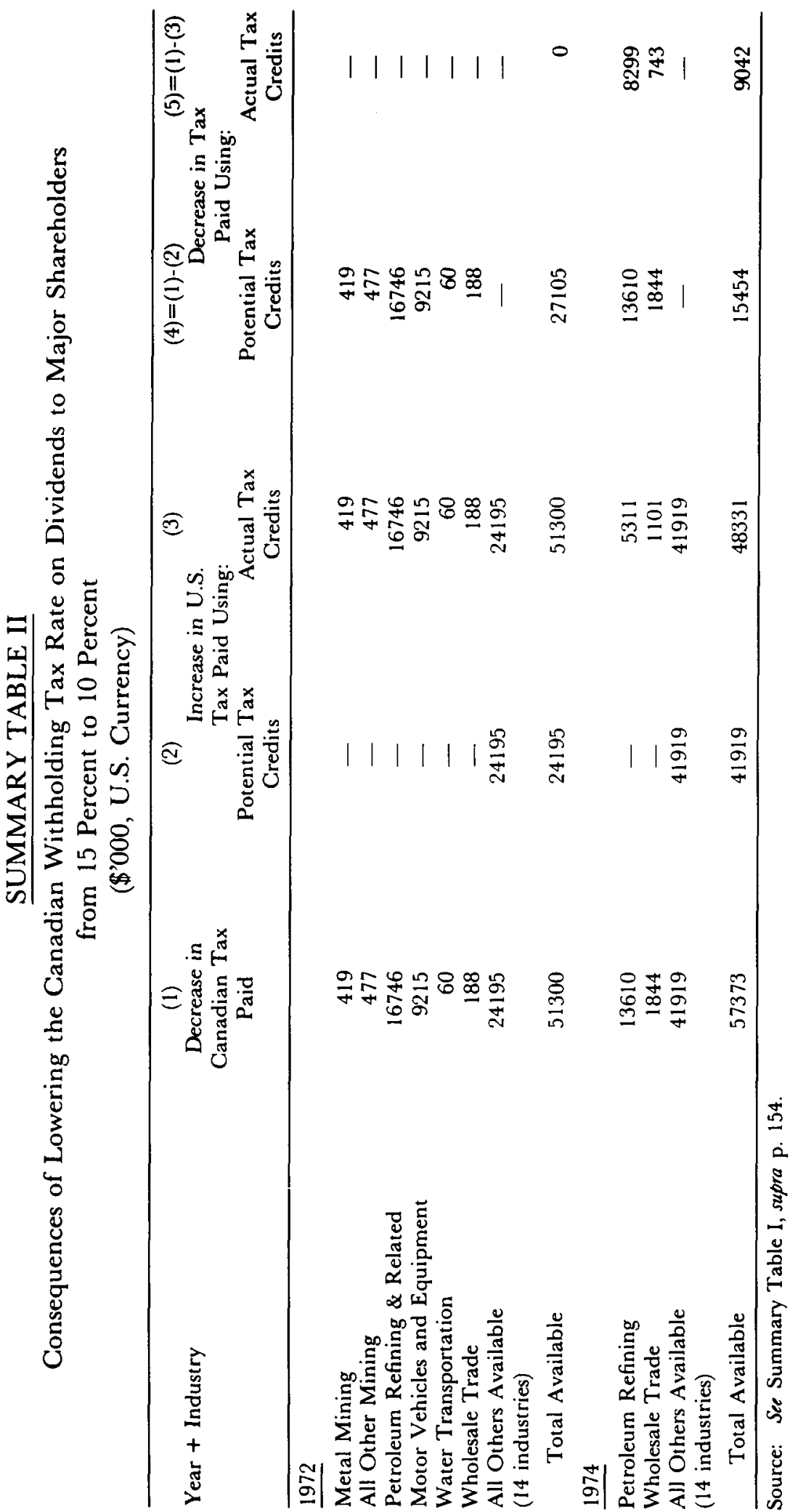


B. Decrease in the Withholding Tax Rate on Dividends to Major Shareholders from 15 to 10 Percent

This section investigates the consequences of withholding tax change proposed in the 1980 Canada-United States Tax Treaty. Under these proposals, a U.S. company owning 10 percent or more of a Canadian subsidiary would have its withholding tax on patriated earnings reduced from 15 to 10 percent.

Summary Table II is constructed to show the impact of such a change in taxes on the dividends and branch profits patriated from U.S.-owned affiliates in Canada. This change in tax policy results in an estimated reduction in the overall tax burden of only six out of twenty-two industries using 1972 data and two out of fifteen industries using 1974 data.

Canadian taxes collected are estimated to fall by $\$ 51$ million using 1972 data and $\$ 57$ million using 1974 data. Assuming the use of actual tax credits, almost 100 percent of the tax savings in Canada would have to be dissipated by increased tax payments to the United States in 1972, and 84 percent in 1974. The other 16 percent is saved by "Petroleum Refining" and "Wholesale Trade." Looking at potential tax credits as the basis for the calculations, $\$ 24$ million (47 percent) in 1972 and $\$ 42$ million (73 percent) in 1974 of the savings on Canadian taxes is absorbed by increased tax collections in the United States. Of the monies remaining with the taxpayers, "Petroleum Refining" receives $\$ 16$ million in 1972 and $\$ 14$ million in 1974. "Motor Vehicles and Equipment" benefits by $\$ 9$ million in 1972.

As above, the fact of overriding importance is the shift of taxes collected from one government to the other. Such changes in Canadian tax policy affecting income from foreign-owned investments tend to alter minimally the burden of the ultimate taxpayers, and therefore have only a slight impact on the incentives to carry on or to expand business in Canada.

\section{Reduction in the Corporate Tax Rate on Manufacturing}

The general tax rate on corporate profits, with respect to manufacturing operations only, was lowered from 46 to 40 percent in the 1972 Budget of the Government of Canada. ${ }^{42}$ To determine what tax transfers and business incentives were created by this reduction with respect to U.S.-owned manufacturing in Canada, the consequences of restoring the rate to 46 percent have been estimated below.

In calculating the earnings and profits content of dividends and the corresponding foreign income taxes paid, the United States uses a last-created-first-declared basis. ${ }^{43}$ Dividends and tax credits are assumed to arise first from the most recent year's earnings and profits and then from the preceding years' earnings and profits if the current year's are not sufficient.

Because the Internal Revenue Service estimates foreign tax credits and taxable income in this way, the increase in foreign tax credits available can be estimated

42. The reduction of 6 percentage points applies to Canadian manufacturing and processing profits for 1973 and subsequent taxation years. See Interpretation Bulletin IT-145R, Department of National Revenue, Taxation, June 19, 1981.

43. See Rev. Rul. 74-550, 1974-2 C.B. 902. 
by applying the change in the corporate income tax rate to the value of dividends and branch profits grossed up for taxes paid. This value of increased foreign tax credits must then be adjusted downward to account for the fact that both dividends and withholding taxes will be reduced approximately proportionally as corporate income taxes are increased.

Summary Table III estimates the consequences, by manufacturing industry, of having decreased the corporate income tax by 6 percentage points for 1974. In the absence of specific information on the subsidiaries, it is assumed that the classification of the U.S. parent companies is identical with the activity of the Canadian subsidiaries for tax purposes.

The values reported in Summary Table III suggest that a very high proportion of the money lost by the government of Canada through the application of the lower corporate tax rate to the U.S. subsidiaries ends up in the coffers of the U.S. government in the form of additional taxes collected. This applies to $\$ 56$ million out of $\$ 72$ million (78 percent) in 1974. The benefits remaining with industry accrue to "Petroleum Refining" which captures, unambiguously, the entire net tax benefit of $\$ 16$ million in 1974 . The preceding estimates of revenue loss to Canada apply only to patriated earnings. In addition to these amounts, there is a revenue loss due to the reduction of taxes applicable to earnings currently retained. Using the overall retention ratio for U.S. investment in Canada of 59 percent, the total tax loss to Canada should be approximately $\$ 175$ million. ${ }^{44}$

These results indicate that incentives arising from adjustments to corporation income tax rates alone will be dampened if a significant proportion of the companies in the targeted industries are subsidiaries of U.S. companies. For these subsidiaries a reduction in Canadian corporation taxes generally results in a reduction of foreign tax credits below the amount of U.S. tax liabilities due on this income. Increased tax payments to the Internal Revenue Service are thereby substituted for payments to Revenue Canada.

\section{III}

\section{CONCLUDing REMARKS}

The taxation of foreign investment by Canada, the United States and Mexico can affect the aggregate level of investment in North America, the distribution of this investment, and the tax revenues it generates among these countries. The essentially bilateral nature of the taxation of the profits of foreign capital can lead to substantial unintended effects from changes in domestic tax rates or regulations. For example, if Canada drops its corporate tax rate to encourage both domestic and foreign investment, then one result is the transfer of tax revenues to the United

44. See Evans \& Jenkins, The Cost of U.S. Direct Foreign Investment, Development Discussion Paper No. 104, Harvard Institute for International Development, Harvard University (November 1980).

Compare our figures (given in U.S. currency) to the estimated aggregate tax expenditures (in Canadian dollars) on the reduction of tax rates on manufacturing and processing profits.

$1976 \$ 280$ million

$1979 \$ \$ 400$ million

Department of Finance, Tax Expenditure Account 37 (Dec. 1979). 
[Vol. 44: No. 3

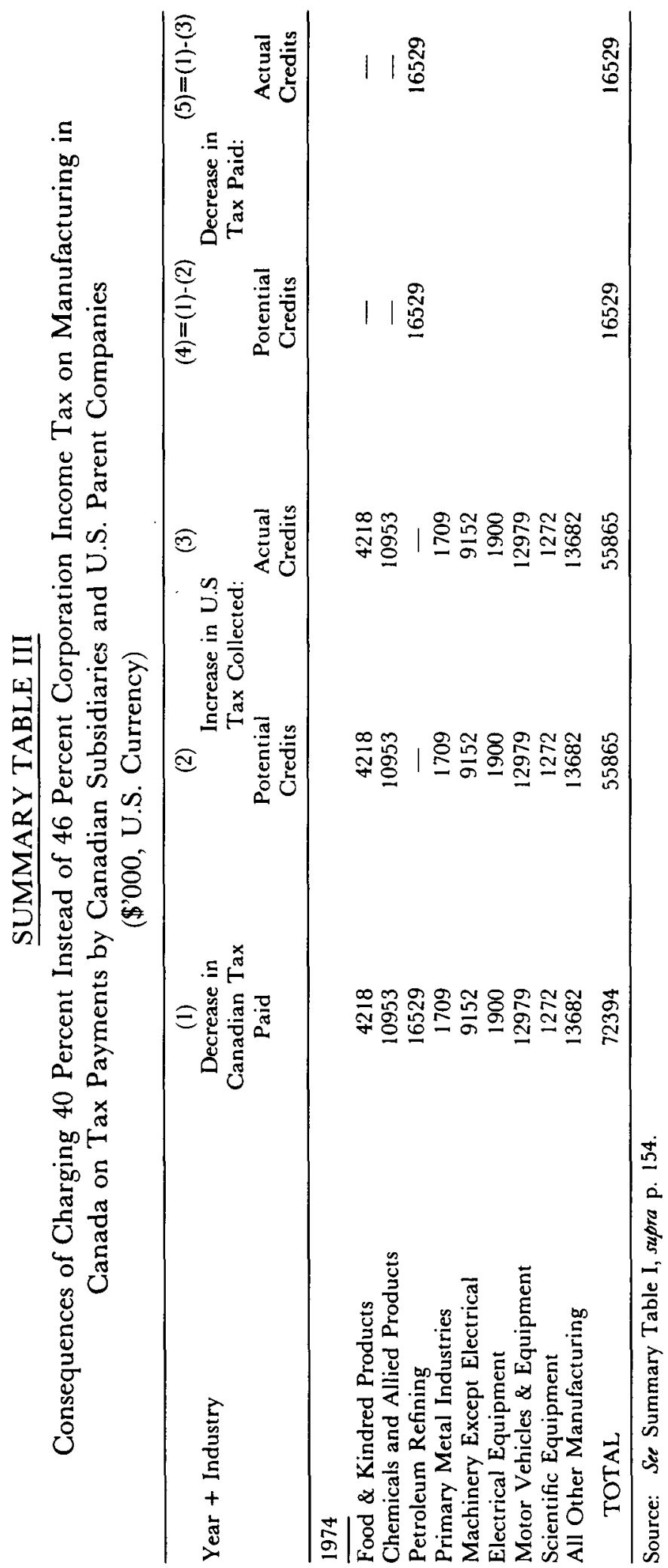


States and other countries with tax rates at or above those in Canada without any increase in foreign investment incentives. The foreign investor still faces the same total tax bill payable to home and host countries. The Canadian authorities should have no particular incentive to make indirect transfers to the United States or to any other foreign treasury; therefore, they should be reluctant to lower taxes on foreign profits. Conversely, a foreign government can be expected to resist Canadian tax hikes.

The United States has been moving toward making it more difficult to have foreign taxes creditable. This tends to make U.S. investment in Canada and Mexico less attractive as the total taxes payable are raised. This investment disincentive is further strengthened by the U.S. requirement for certain domestic expenses to be deducted from foreign profits. Given the importance of U.S. foreign investments, both Canada and Mexico will be under pressure to align their taxation systems with U.S. foreign tax credit requirements.

The bilateral nature of foreign investment taxation makes it a component of foreign aid. When less developed countries seek to attract foreign investment through low corporate tax rates, such incentives can be neutralized by home-country taxation of the repatriated profits. The home country must establish a taxsparing agreement by which it forgoes taxing the newly exposed tax base in order to make the tax cut effective. Canada and the United States must decide whether they will agree to make such tax expenditures part of their aid packages to Mexico. 



\section{II \\ CANADIAN FEDERALISM}


